THE VALUATION OF PUTTABLE BONDS:

\title{
AN APPLICATION OF THE COX, INGERSOLL AND ROSS MODEL TO ITALIAN TREASURY OPTION CERTIFICATES ${ }^{(*)}$
}

by E. Barone and D. Cuoco

$\left(^{*}\right)$ Banca d'Italia - Servizio Studi. This paper has been presented at the I annual meeting of the Northern Finance Association, held in Ottawa on September 23-24, 1989. We are grateful to Peter Carr and Giovanni Barone-Adesi for helpful comments. The usual disclaimer applies. 


\section{SUMMARY}

The Italian Treasury's puttable bonds (Certificati del Tesoro con opzione di rimborso anticipato CTOs) are the first example in Italy of retractable/extendible bonds, which have been used on the Canadian market for some time and recently been adopted on the Euromarket. In this paper the single-factor version of the Cox, Ingersoll and Ross model is used to determine the equilibrium value of CTOs at issue. The simulation of the effects of changes in their features provides useful information on the optimal design of CTOs.

\section{CONTENTS}

1. INTRODUCTION 1

2. THE FEATURES OF ITALIAN TREASURY OPTION CERTIFICATES - CTOS 1

3. TREASURY OPTION CERTIFICATES AS RETRACTABLE/EXTENDIBLE BONDS 1

4. THE OPTIMAL EXERCISE STRATEGY 3

5. THE COX, INGERSOLL AND ROSS MODEL 3

5.1 An equilibrium model 3

5.2 The valuation of bonds 4

5.3 The valuation of derivative securities 5

6. THE VALUATION OF TREASURY OPTION CERTIFICATES 6

6.1 Estimation of the model's parameters 6

6.2 Results 6

7. THE EFFECT OF CONTRACTUAL FEATURES ON THE VALUE OF TREASURY

OPTION CERTIFICATES

$\begin{array}{lll}7.1 & \text { Striking price of the option } & 10\end{array}$

$\begin{array}{ll}7.2 & \text { Option maturity } \\ 7.30\end{array}$

$\begin{array}{ll}7.3 \text { Bond maturity } & 11\end{array}$

$\begin{array}{lll}7.4 & \text { Coupon rate } & 12\end{array}$

8. CONCLUSIONS 12

APPENDIX A $\quad 13$

$\begin{array}{ll}\text { REFERENCES } & 15\end{array}$ 


\section{INTRODUCTION}

The Italian puttable bonds (Certificati del Tesoro con Opzione - CTOs) issued on 1 December 1988 are fixed rate securities with a maturity of 8 years and an option allowing holders to obtain early redemption at the end of the fourth year.

After describing the features of CTOs in (§2), we show that they can be considered either as 4year bonds with a call option or as 8-year bonds with a put option $(\S 3)$. This analytical framework is then used to derive some arbitrage constraints on the value of puttable bonds and to determine the optimal strategy for exercising the right to early redemption $(\S 4)$.

The $\S 5$ contains a short description of the single-factor formulation of the Cox, Ingersoll and Ross model. Developed in the context of general equilibrium, this model permits the valuation of any financial asset whose price depends exclusively on the current term structure of interest rates. After obtaining the maximum-likelihood estimates of the parameters, the Cox, Ingersoll and Ross model is used to determine the value of CTOs at issue (Section 6). Finally, Section 7 shows the results of simulations analyzing the effect on the value of CTOs of various specifications of the early redemption price, the date on which the early redemption option matures and the maturity and coupon rate of the bond.

\section{THE FEATURES OF ITALIAN TREASURY OPTION CERTIFICATES - CTOS}

The issue of the first CTOs was announced on 22 November 1988. The rate of interest was fixed at $10.25 \%$, payable on a deferred basis by way of semi-annual coupons (1 June and 1 December) amounting to $5.125 \%$ ( $4.4845 \%$ net of the $12.5 \%$ withholding tax) and interest accruing as of 1 December 1988. Redemption at maturity was fixed at face value $(99.375 \%$ net of the withholding tax on the redemption premium). The holders of these certificates are entitled to have them redeemed early after 4 years, in the period from 1 to 10 December 1992, by sending a special application form to one of the branches of the Bank of Italy between 1 and 10 November 1992..

The CTOs were sold using the uniform price auction method, whereby securities are allocated at the lowest of the prices offered by successful tenderers. The floor price (below which the Treasury does not accept offers) was fixed at 95 per ${ }^{1} 00$ of nominal capital. The offers of the participants in the auction (the Bank of Italy, banks and their central institutes and authorized financial companies) had to reach the Bank of Italy by 12.30 on 29 November 1988.

The auction price of the option certificates was equal to the floor price (95). Only a part of the 1,500 billion lire of certificates was subscribed (444 billion lire by market operators and 150 billion by the Bank of Italy). Settlement was made on 1 December 1988 at the auction price (without payment of day-to-day interest).

\section{TREASURY OPTION CERTIFICATES AS RETRACTABLE/EXTENDIBLE BONDS}

Treasury option certificates allow their owners to take advantage of a fall in interest rates (since they are fixed rate securities) while protecting them from capital losses caused by a rise in interest rates (through the early redemption option). They are the first example in Italy of the retractable/extendible bonds common in the Canadian market and recently adopted in the Euromarket. In practice, CTOs can be considered indifferently as bonds with a maturity of 8 years plus a put option permitting them to be sold at the end of the fourth year, ${ }^{2}$ at a striking price equal to the face value (retractable bonds), or as bonds with a maturity of 4 years plus a call option permitting the purchase at par of another 4-year bond (extendible bonds).

More generally, in the case of a retractable/extendible bond with an option having striking price $K$, maturity $T$ and written on a bond maturing at time $s$, we have:

\footnotetext{
${ }^{1}$ This advance notification of the intention to opt for early redemption is necessary, but is not binding on bondholders.

${ }^{2}$ In view of the shortness of the exercise period, it can be assumed for explanatory purposes that the early redemption option is exercisable on a single day (European option) rather than during a period of time (American option).
} 
TABLE 1 Demonstration of the arbitrage relationship $c(t, K, T, s, T n)=p(t, K, T, s, T n)+B(t, s, T n)-B(t, T, T n)-(K-1) B(t, s, 0)$

\begin{tabular}{lcc}
\hline \multirow{2}{*}{ Current value of the portfolio } & \multicolumn{2}{c}{ Final value of the portfolio at the expiration date } \\
\cline { 2 - 3 } & $B(T, s, T n)<K$ & $B(T, s, T n)>K$ \\
\hline$c(t, K, T, s, T n)$ & 0 & $B(T, s, T n)-K$ \\
$-p(t, K, T, s, T n)$ & $B(T, s, T n)-K$ & 0 \\
$-B(t, s, T n)$ & $-B(T, s, T n)-T n$ \\
$+B(t, T, T n)$ & $1+T n$ & $-B(T, s, T n)-T n$ \\
$+(K-1) B(t, T, 0)$ & $K-1$ & $1+T n$ \\
& & \\
&
\end{tabular}

where

$W(t, K, T, s, T n)$ : is the value at time $t$ of a retractable/extendible bond with coupon rate $T n$, and an option having striking price $K$, maturity $T$ and written on a bond maturing at time $s(s>T>t) ; B(t, s, T n)$ is the value at time $t$ of a straight bond with coupon rate $T n$, maturity $s$ and face value 1 ;

$c(t, K, T, s, T n)$ : is the value at time $t$ of a call option with striking price $K$ maturity $T$, and written on a bond with coupon rate $T n$ and maturity $s$;

$p(t, K, T, s, T n)$ : is the value at time $t$ of a put option with striking price $K$ maturity $T$, and written on a bond with coupon rate $T n$ and maturity $s$.

The equality between the last two members of (1) is due to the put-call parity for European bond options (i.e. for those exercisable only at maturity): ${ }^{3}$

$$
\begin{aligned}
c(t, K, T, s, T n) & =p(t, K, T, s, T n)+B(t, s, T n)+ \\
& -B(t, T, T n)-(K-1) B(t, T, 0) .
\end{aligned}
$$

To demonstrate equation (2), consider the portfolio created by (1) buying a call option and selling a put option (both with striking price $K$ maturity $T$ ) written on a bond with coupon rate $T n$ and maturity $s$, (2) selling a bond with maturity $s$ and buying a bond with maturity $T$ (both with coupon rate $T n$ ), and (3) buying $K-1$ pure discount bonds pure discount bonds with maturity $T$. This portfolio produces a zero cash flow from $t$ to $T$ (since the interest receivable on the bond purchased is exactly equal to that payable on the bond sold) and has a final value of zero at time $T$ (Table 1 ). Accordingly, its current value has to be zero:

$$
c(t, K, T, s, T n)-p(t, K, T, s, T n)-B(t, s w, T n)+B(t, T, T n)+(K-1) B(t, T, 0)=0 .
$$

(QED).

It can be seen from equation (2), that the greater $B(t, s, T n)$ is compared with $B(t, T, T n)+(K-$ 1) $B(t, T, 0)$, the less the call option is worth compared with the put option. In particular, the more sharply the yield curve rises, the less the call option is worth.

In addition, since the value of a call or put option is non-negative, equation (1) gives:

$$
W(t, K, T, s, T n)>B(t, T, T n)+(K-1) B(t, T, 0)
$$

and

$$
W(t, K, T, s, T n)>B(t, s)
$$

\footnotetext{
${ }^{3}$ In the special case of options written on pure discount bonds, the put-call parity reduces to the following expression: $c(t, K, T, s, 0)=p(t, K, T, s, 0)+B(t, s, 0)-K B(t, T, 0)$.
} 
whence

$$
W(t, K, T, s, T n)>\max [B(t, T, T n)+(K-1) B(t, T, 0), \quad B(t, s)] .
$$

The foregoing relationship implies that, in the absence of arbitrage opportunities, the price of a CTO, which is equivalent to a retractable/extendible bond with a striking price equal to the par value $(K-$ 1) must exceed both that of a 4-year security and that of an 8-year security.

The option granted to bondholders thus allows CTOs to be issued at a higher price (or at a lower coupon rate) than a straight fixed rate bond of the same maturity would require.

\section{THE OPTIMAL EXERCISE STRATEGY}

Equation (1) defines the optimal strategy for exercising the option of a retractable/extendible bond and gives the value of the security on the day the option is exercised $(t=T)$ :

$$
\begin{aligned}
W(T, K, T, s, T n) & =1+(K-1)+\max [B(T, s, T n)-K, 0]= \\
& =B(T, s, T n)+\max [K-B(T, s, T n), 0]= \\
& =\max [B(T, s, T n), K] .
\end{aligned}
$$

Equation (4) implies that buyers of CTOs will opt for early redemption at the end of the fourth year if the current price of a 4-year security with a semi-annual coupon of $5.125 \%$ is less than par (i.e. if the market rate for the 4-year maturity is higher than $10.51 \%$ ). At that date, if they are not redeemed, CTOs will have a price above par.

\section{THE COX, INGERSOLL AND ROSS MODEL}

\subsection{An equilibrium model}

In order to determine the value of a retractable/extendible bond, it is necessary to specify an equilibrium model of the bond market.

The Cox, Ingersoll and Ross model gives the term structure of interest rates in conditions of general equilibrium and is an important reference point for modern financial theory. ${ }^{4}$ In the singlefactor formulation of the model it is assumed that:

1) the instantaneous interest rate $(r)$ is governed by a mean-reverting process described by the following stochastic differential equation:

$$
d r=\kappa(\mu-r) d t+\sigma \sqrt{r} d z
$$

where $\kappa$ is the speed of adjustment of the interest rate $r$ towards its long-term value $1, \mu, \sigma^{2} r$ is the instantaneous variance of $d r$ and $d z$ is a standard Wiener process;

2) the expected instantaneous rate of return on bonds of all maturities is equal to the interest rate $r$ plus a risk premium (Local Expectations Hypothesis):

$$
E\left(\frac{d B}{B}\right)=r+\frac{\lambda r B_{r}}{B}
$$

where $-\lambda$ is the market price of the risk and $r B r / B$ is the elasticity of the bond price $(B)$ with respect to $r$;

3) the usual perfect market assumptions apply.

With these hypotheses, it can be shown that if the value $H=H(r, t, T)$ of a financial asset depends exclusively on the current term structure, it is given (in the interval between two successive coupons) by the following differential stochastic equation:

$$
1 / 2 \sigma^{2} r H_{r r}+[\kappa(\mu-r)-\lambda r] H_{r}+H_{t}-r H=0 .
$$

\footnotetext{
${ }^{4}$ Cf. J. Cox, J. Ingersoll e S. Ross (1985).
} 
This equation can be solved once the appropriate boundary condition for $H(r, T, T)$ has been imposed on the basis of the features of each individual financial asset.

\subsection{The valuation of bonds}

For the price $P(r, t, s)=B(r, t, s, 0)$ of a pure discount bond with a residual life $\tau=s-t$ the solution of equation (7), subject to the following boundary condition:.

$$
P(r, s, s)=1
$$

is

$$
P(r, t, s)=F(t, s) e^{-G(t, s) r}
$$

where

$$
F(t, s)=\left[\frac{\phi_{1} e^{\phi_{2} \tau}}{\phi_{2}\left(e^{\phi_{1} \tau}-1\right)+\phi_{1}}\right]^{\phi_{3}}
$$

and

$$
G(t, s)=\left[\frac{\left(e^{\phi_{1} \tau}-1\right)}{\phi_{2}\left(e^{\phi_{1} \tau}-1\right)+\phi_{1}}\right] .
$$

Equation (9) expresses the value of a pure discount bond with maturity $\tau$ in terms of the state variable $r$ and of the three parameters $\phi_{1}, \phi_{2}$ e $\phi_{3}$, where:

$$
\begin{gathered}
\phi_{1}=\sqrt{(\kappa+\lambda)^{2}+2 \sigma^{2}} \\
\phi_{2}=\frac{\kappa+\lambda+\phi_{1}}{2} \\
\phi_{3}=\frac{2 \kappa \mu}{\sigma^{2}} .
\end{gathered}
$$

Equation (9) permits the whole term structure to be determined, since the interest rate at time $t$ for maturity $s, R(t, s)$, is equal to:

$$
R(t, s)=-\frac{\ln [P(r, t, s)]}{\tau}
$$

When $s \rightarrow 0$, we have $R(t, 0) \rightarrow r$, while for $s \rightarrow \infty$ :

$$
R(t, \infty) \rightarrow\left(\phi_{1}-\phi_{2}\right) \phi_{3} .
$$

With the discount factors $P(r, t, s)$ known, the current value of any coupon bond with maturity $s$ is expressed by:

$$
B(r, t, s, T n)=\sum_{i=1}^{n} a_{i} P\left(r, t, s_{i}\right)
$$

where $a_{i}=a_{i}(T n)$ is the payment at time $s_{i}\left(t<s_{i} \leq s_{n}=s\right)$. 


\subsection{The valuation of derivative securities}

For a call option written on a pure discount bond, differential equation (7) has to be solved subject to the boundary condition:

$$
c(r, T, K, T, s, 0)=\max [P(r, T, s,)-K, 0] .
$$

Cox, Ingersoll and Ross closed-form solution to the above problem is:

$$
c(r, t, K, T, s)=P(r, t, s) \chi^{2}\left(d_{1}, d f_{1}, n c_{1}\right)-K P(r, s, T) \chi^{2}\left(d_{2}, d f_{2}, n c_{2}\right)
$$

where $\chi^{2}(d, d f, n c)$ is the non-central chi-square distribution function, with $d f$ degrees of freedom and non-centrality parameter $n c$, evaluated at $d$, and:

$$
\begin{gathered}
d_{1}=2 r^{*}[\varphi+\psi+G(T, s)] \\
d_{2}=2 r^{*}(\varphi+\psi) \\
d f_{1}=d f_{2}=2 \phi_{3} \\
n c_{1}=\frac{2 \varphi^{2} r e^{\phi_{1}(T-t)}}{\varphi+\psi+G(T, s)} \\
n c_{2}=\frac{2 \varphi^{2} r e^{\phi_{1}(T-t)}}{\varphi+\psi} \\
\varphi=\frac{2 \phi_{1}}{\sigma^{2}\left[e^{\phi_{1}(T-t)}-1\right]} \\
\psi=\frac{2 \phi_{2}}{\sigma^{2}} \\
r^{*}=\frac{\ln [F(T, s) / K]}{G(T, s)}
\end{gathered}
$$

The value $r^{*}$, defined by (26), is the critical interest rate below which the call option is exercised. It is obtained by putting $P(T, s)=K$ and solving for $r$.

The value at time $t$ of a put option can be obtained by the put-call parity given in (2):

$$
p(r, t, K, T, s, 0)=c(r, t, K, T, s, 0)-P(r, t, s)+K P(r, t, T)
$$

Jamshidian (1989) has shown that, in the hypothesis of a one-factor term structure model, an option on a coupon bond is equivalent to a portfolio of options on pure discount bonds:

$$
c(r, t, K, T, s, T n)=\sum_{j=m}^{n} a_{j} c\left(r, t, K_{j}, T, s_{j}, 0\right)
$$

where $a_{j}$ is the bond's payment at time $s_{j}\left(T<s_{m} \leq s_{j} \leq s_{n}=s\right), r^{*}$ is the solution to $B\left(r^{*}, T, s, T n\right)=K$ and $K_{j}=P\left(r^{*}, T, s_{j}\right)$.

Equation (1), together with (18) and (28), gives a closed-form evaluation formula for retractable/extendible bonds. 


\section{THE VALUATION OF TREASURY OPTION CERTIFICATES}

\subsection{Estimation of the model's parameters}

The parameters of the Cox, Ingersoll and Ross model can be estimated in two ways. In the two-stage approach, first the parameters $\kappa, \mu$ and $\sigma$ of process (5) followed by the instantaneous interest rate, are estimated using a short-term rate time series, and then $\lambda$ on the basis of equation (16). ${ }^{5}$ In the one-stage approach, the model parameters (and the state variable $r$ ) are determined simultaneously on the basis of (16) using a non-linear regression technique method or the generalized method of moments. ${ }^{6}$

The one-stage non-linear regression approach permits the estimation of the parameters $\phi_{1}, \phi_{2}$ and $\phi_{3}$, defined by equations (12), (13) and (14), but does not allow $\kappa, \mu$ and $\lambda$. to be estimated separately However, $\sigma^{2}$ can be determined using the following equation:

$$
\sigma^{2}=2\left(\phi_{1} \phi_{2}-\phi_{2}^{2}\right)
$$

On the other hand, the method of moments is difficult to use in the case of coupon bonds. ${ }^{7}$ Accordingly, the parameters of the Cox, Ingersoll and Ross model have been obtained here with non-linear regression (Marquardt's method), by minimizing the sum of the squares of the differences between the prices of Treasury bonds listed on the secondary market and the theoretical prices given by equation (16).

To this end we assumed that the differences between actual and theoretical prices were mutually independent and normally distributed, with a mean of zero and a variance proportional to the derivatives of the bond prices with respect to their yields to maturity (i.e. to the products of their durations and prices).

The estimates were therefore made using generalized least squares, dividing both members of equation (16) by the square root of the derivatives.

\subsection{Results}

The parameters of the Cox, Ingersoll and Ross model were estimated on the basis of the (cum coupon) prices of the Treasury bonds listed on the secondary market (the Milan Stock Exchange and the screen-based market) on 28 November 1988, with settlement on 1 December..

The estimates obtained were equal to 0.09634 for the instantaneous interest rate $r$ and 0.25881 , 0.25124 and 15.511 for the parameters $\phi_{1}, \phi_{2}$ and $\phi_{3}$, respectively. The value of $\sigma$, obtained on the basis of equation (20), was 0.0617 , implying a standard deviation of the instantaneous interest rate $(\sigma \sqrt{r})$ of 0.01914 .

As mentioned above, the original parameters of the model, $\kappa, \mu$ and $\lambda$ cannot be determined separately on the basis of $\phi_{1}, \phi_{2}$ and $\phi_{3}$. However, for every possible value of one of the three parameters the values of the other two can be obtained (Figure 1 - Figure 3).

In particular, for $\lambda$ equal to zero (implying a zero risk premium), the velocity of adjustment $k$ and the long-term value $\kappa$ and the long-term value $\mu$ of the instantaneous interest rate $r$ are equal to 0.24367 and 0.12107 respectively; per for negative values of $\lambda$ (i.e. for positive risk premiums), $\kappa$ increases while $\mu$ decreases.

The yield curve estimated on the basis of these parameters was upward-sloping, lying between the instantaneous rate of 0.09634 and the long-term asymptotic rate by given (15) of 0.1174 (Figure 4 and Table a1).

Almost all the variance observed in Treasury bond prices was explained by the model $\left(R^{2} \approx 1\right)$ : the absolute differences between actual and theoretical prices were less than $0.1 \%$ in $45 \%$ of the cases and less than $0.5 \%$ in $90 \%$ of the cases (Figure 5 and Table a2).

\footnotetext{
${ }^{5}$ See A. Ananthanarayanan and E. Schwartz (1980). For an application of the two-stage approach to the Italian market, see E. Barone and R. Cesari (1986).

${ }^{6}$ For estimations using non-linear regression techniques, see S. Brown and P. Dybvig (1986) and R. Brown and S. Schaefer (1988). For an estimation based on the method of moments, see M. Gibbons and K. Ramaswamy (1986).

${ }^{7}$ See Gibbons and Ramaswamy (1986).
} 


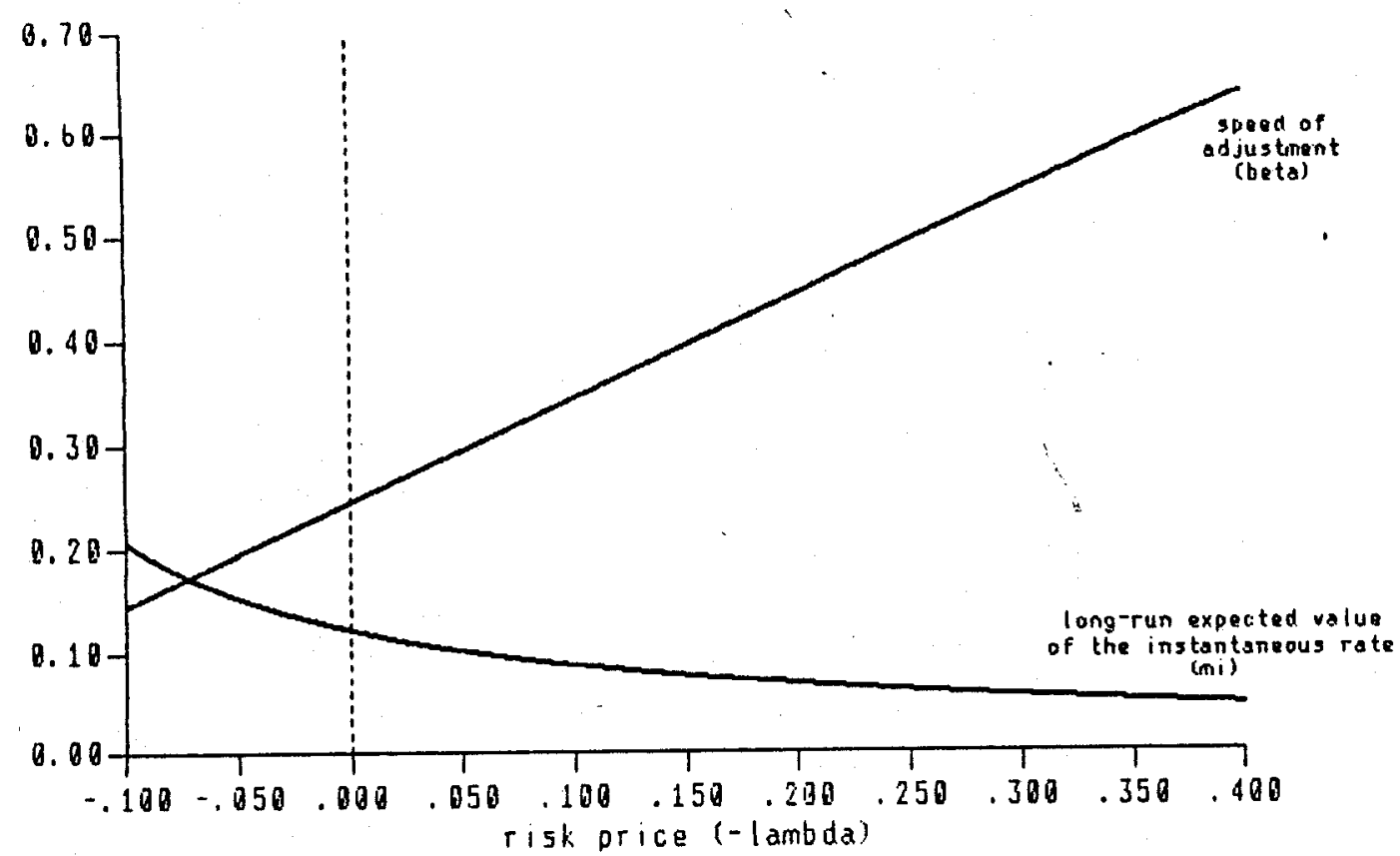

N. B. The curves were obtsined on the basis of the astimated values of $f 1$. f2 and $f 3$ co. 25881 . 0. 25124. 15.511).

Figure 2

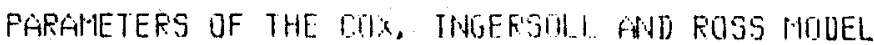

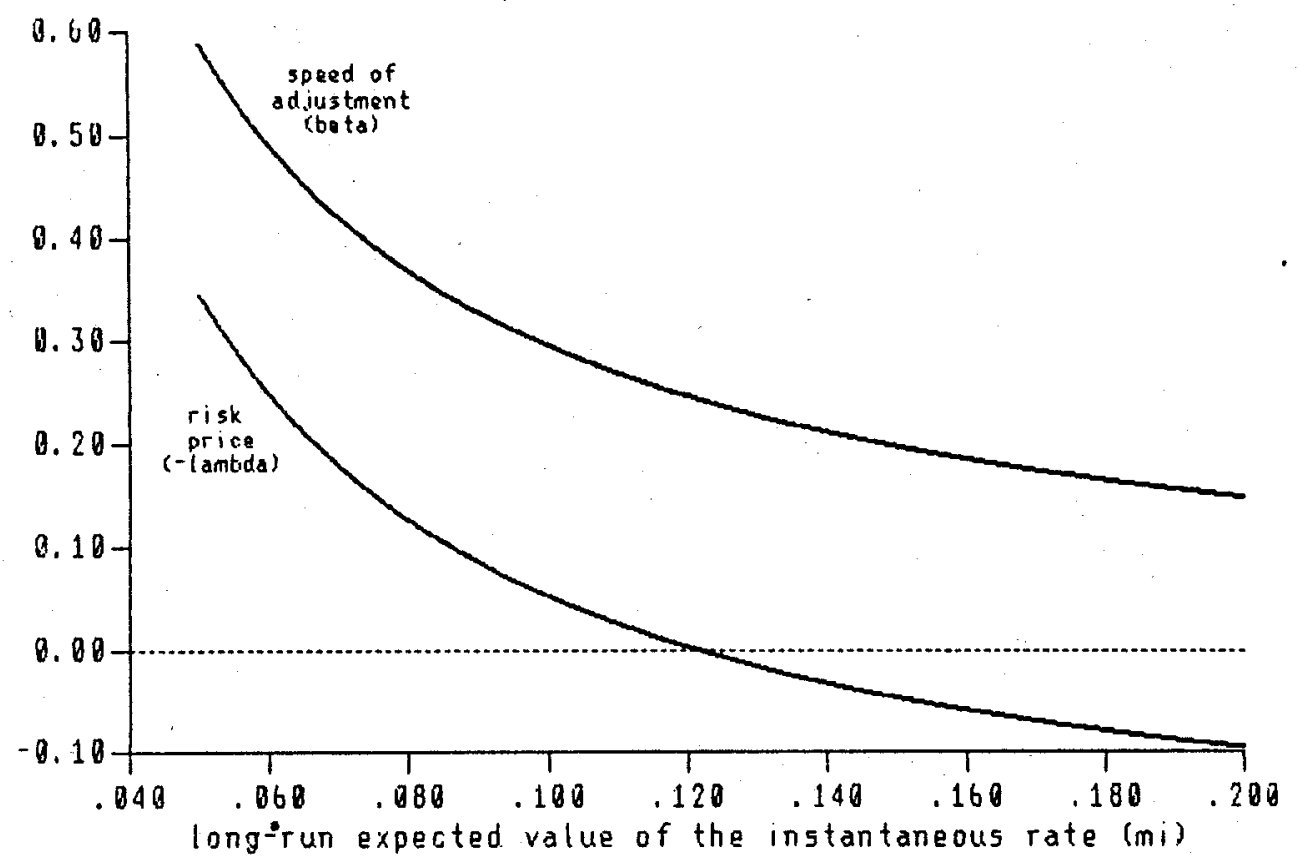

N. B. The curves were obtained on the basis of the estimated values of $f L$, $f 2$ and $f 3$ (B.25861. 0.25124, 15.511). 


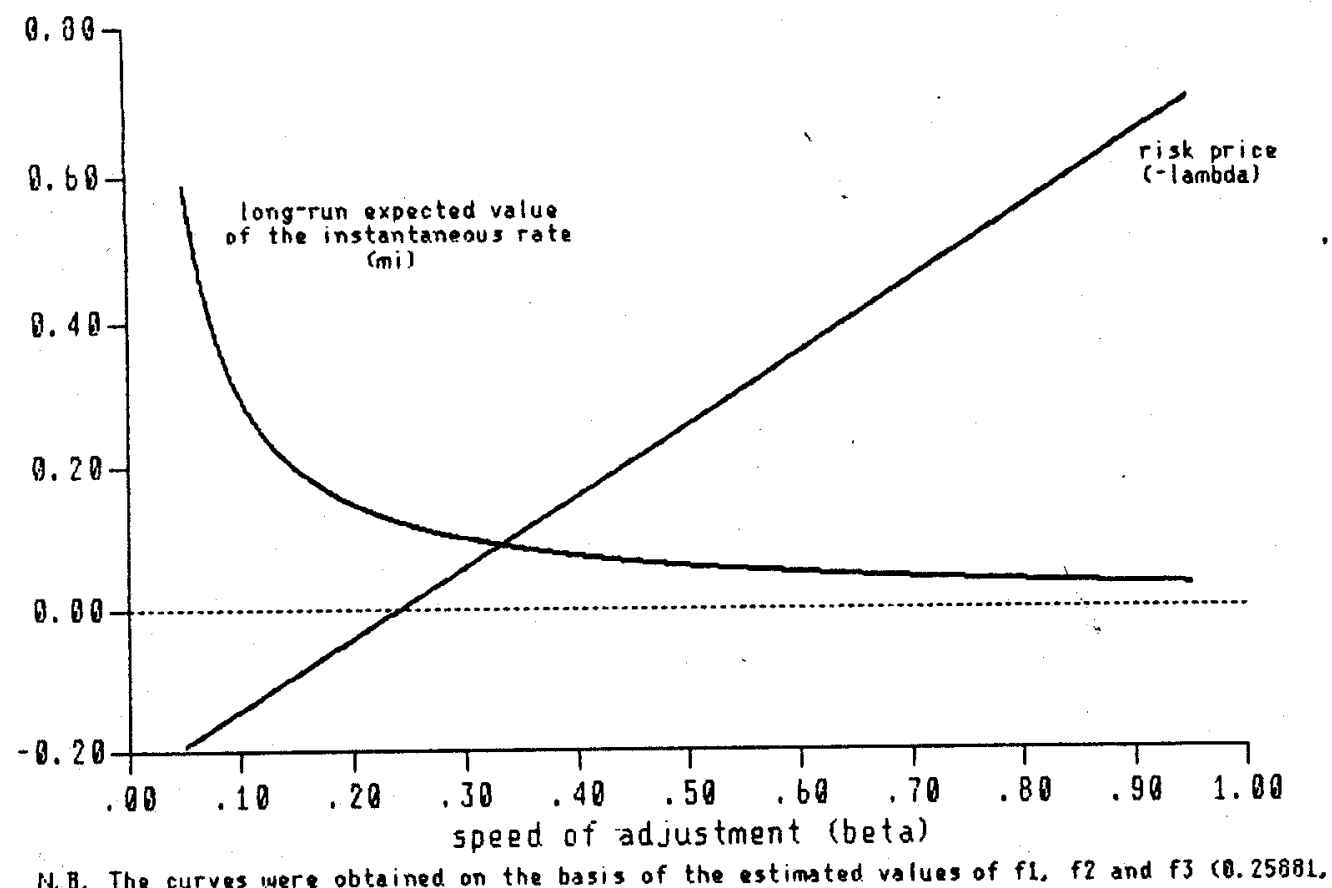

N. B. The curves were obtained on the basis of the estimated values of $f 1$, f2 and $f 3(0.25881$. 0.25124. 15.511)

NET YILLD CURVE

Figure 4

Raw data: Treasury bonds

Stock. Exchange and Wire Markot Prices

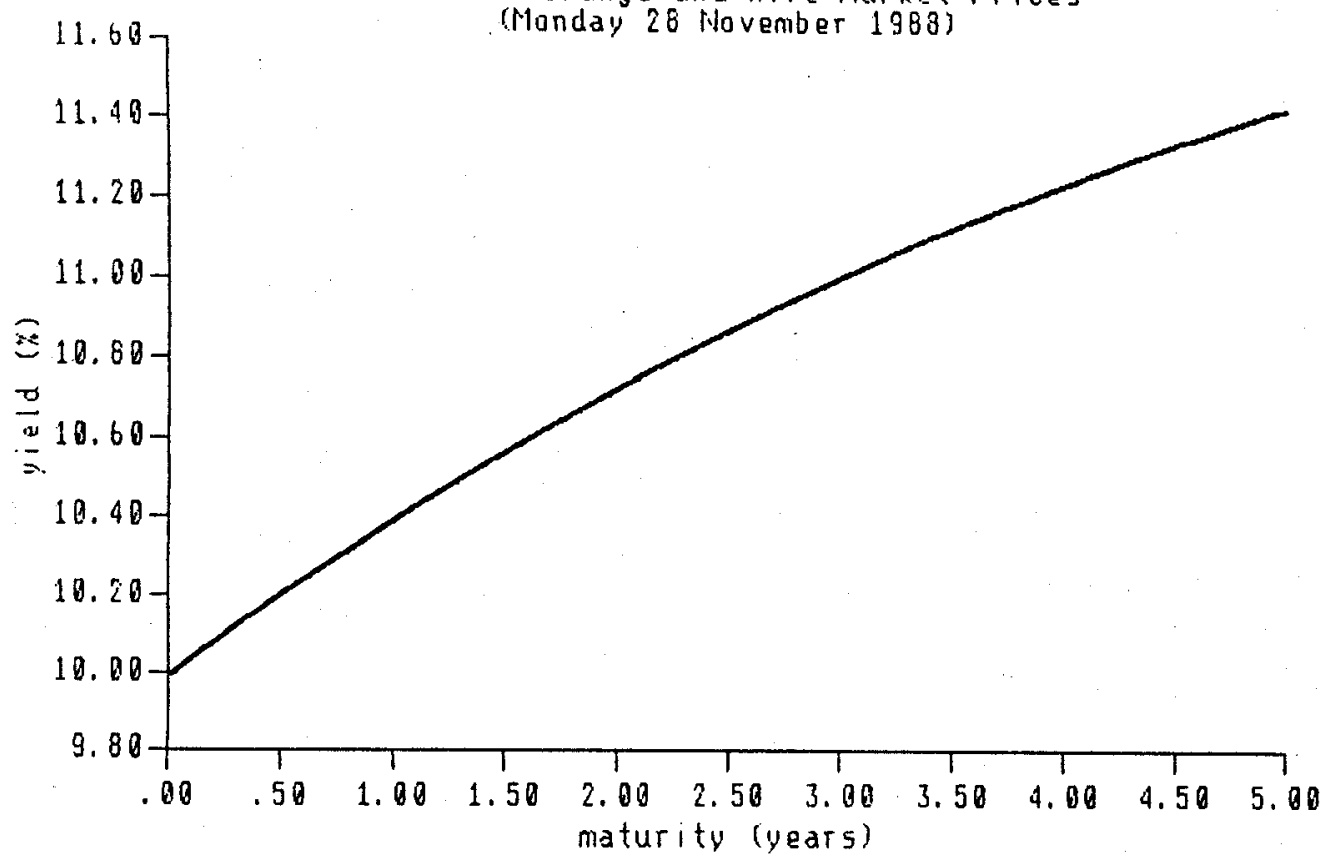

W. B. The parameters of the curve were obtained by minimizing the sum of the snuared differences between actual prices and thase given by the Cox, Ingersoll and Ross model. 


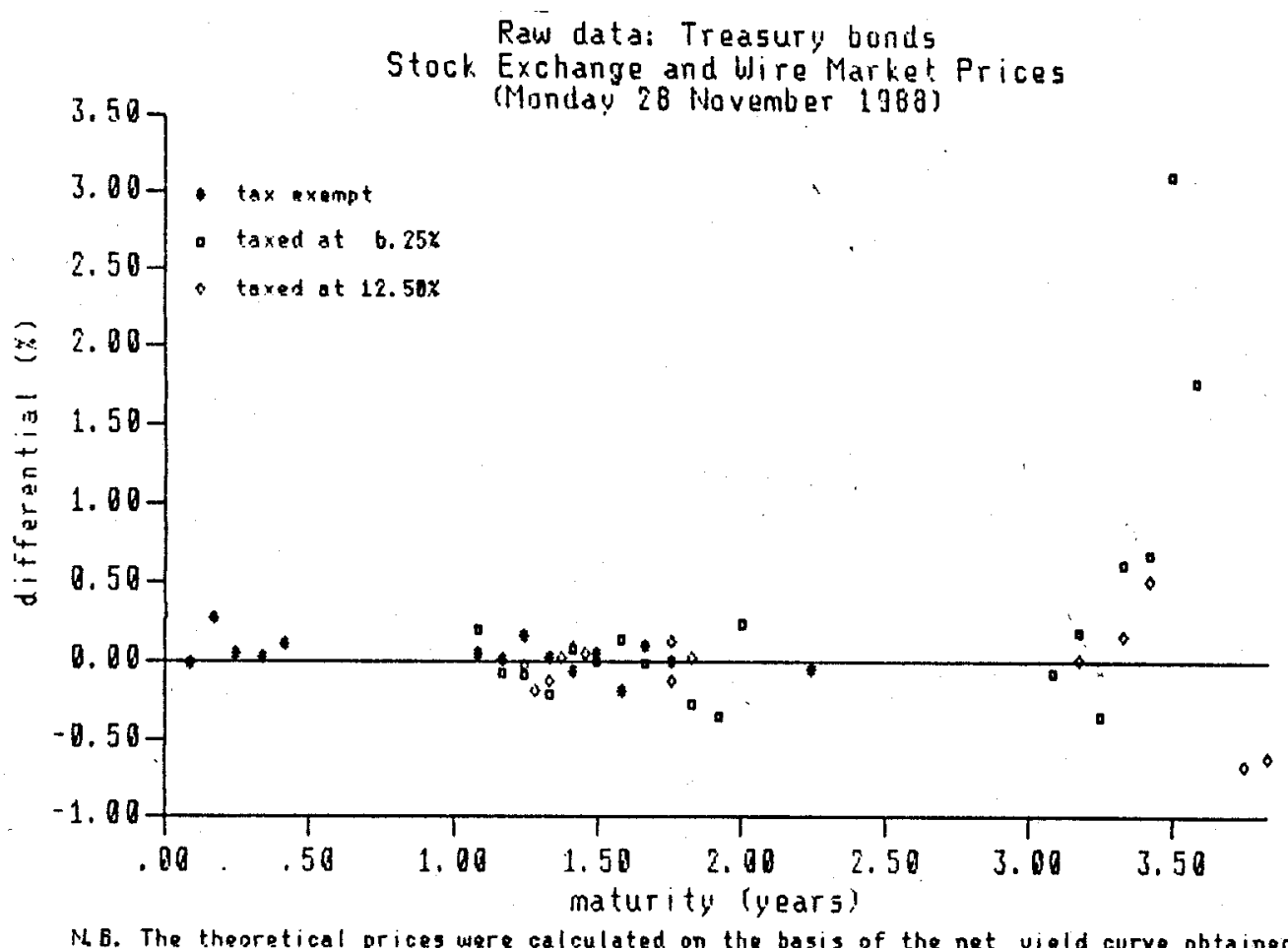

MB. The theoretical prices were calculated on the basis of the net yield curve obtained by sstimating the Cox. Ingersoll and Ross model.

Given the estimated parameters, equation (1) was used to evaluate CTOs at issue. This gave a value of 94.51 , which corresponds to a value of 0.06 for the call option and of 5.52 for the put option (Table 2).

TABLE 2 Breakdown of the price of CTO

\begin{tabular}{lr}
\hline 4-year bond & 94.45 \\
Call option & 0.07 \\
Total & 94.52 \\
& 88.99 \\
8-year bond & 5.53 \\
Put option & 94.52 \\
Total & \\
\hline
\end{tabular}

These results reflect the shape of the yield curve. An upward-sloping curve generally implies expectations of an increase in rates and hence of a fall in the market prices of fixed rate bonds, resulting in a low value of the option to extend the bond and a relatively high value for the option to obtain early redemption.

The model also enables the expected future price of CTOs to be calculated. The upward slope of the yield curve is consistent with expectations of early redemption at the end of the fourth year. The expected prices of CTOs therefore virtually coincide with that of an ordinary 4-year bond and is considerably higher than that of an 8-year bond with the same coupon (Figure 6). 


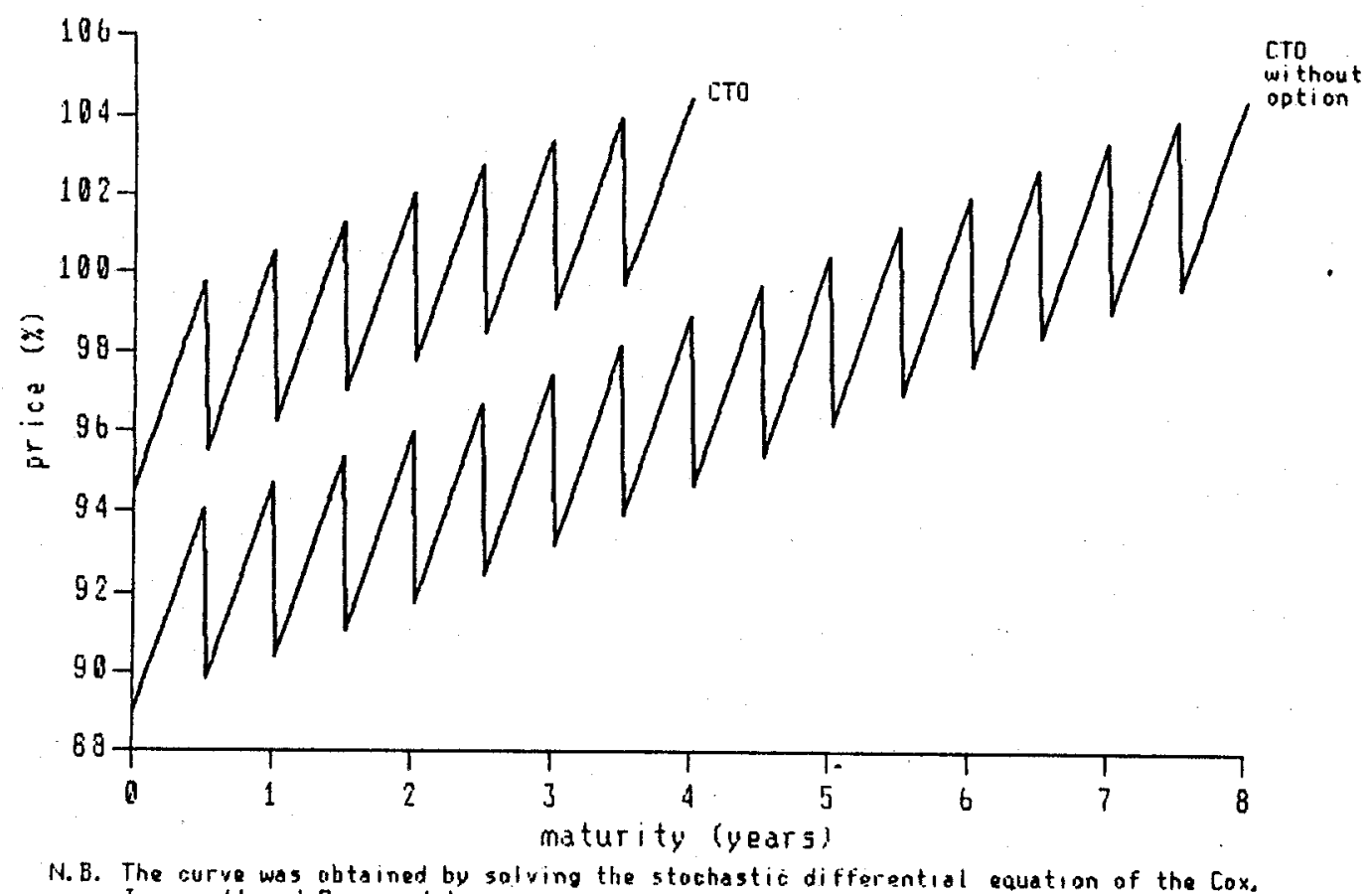
Ingersoll and Ross model.

\section{THE EFFECT OF CONTRACTUAL FEATURES ON THE VALUE OF TREASURY OPTION CERTIFICATES}

The valuation model was also used to simulate the effects of changes in the contractual features of CTOs on their value at issue and on the probability of their being held to maturity. The simulations were made with reference to three different yield curves: the first rising (curve A); the second flat (curve B); and the third falling (curve C). Curve A is that used in the preceding analysis. The parameters of the curves $B$ and $C$ were fixed to give a value of $r$ equal to the estimated one (0.0617) and a long-term asymptotic interest rate equal to respectively 0.09634 (the estimated value of the instantaneous interest rate) and 0.075262 (by symmetry with curve A).

\subsection{Striking price of the option}

The 8-year CTOs issued in December 1988 are redeemable at par at the end of the fourth year. Table 3 shows the effect of varying the early redemption price between 97 and 103, which is equivalent to varying the striking price $K$ of the put and call options.

The higher the redemption price, the lower the probability that the security will be held to maturity. Accordingly, the value of the early redemption (put) option increases and that of the extension (call) option decreases. Furthermore, since a CTO with a higher redemption price is obviously more advantageous than an otherwise equal bond, its value must be an increasing function of the early redemption price.

\subsection{Option maturity}

Lengthening the option maturity has two effects: on the one hand, it reduces the present value of the expected gain and, on the other, it alters the probability of large oscillations in the price of the under- 
TABLE 3 Theoretical prices of the CTO as a function of the striking price

\begin{tabular}{|c|c|c|c|c|c|c|c|c|}
\hline$K$ & & 97 & 98 & 99 & 100 & 101 & 102 & 103 \\
\hline \multirow{3}{*}{ CALL } & $A$ & 0.26 & 0.17 & 0.1 & 0.06 & 0.03 & 0.02 & 0.01 \\
\hline & B & 1.44 & 1.12 & 0.84 & 0.62 & 0.44 & 0.3 & 0.19 \\
\hline & $C$ & 4.2 & 3.62 & 3.08 & 2.58 & 2.12 & 1.71 & 1.34 \\
\hline \multirow{3}{*}{ PUT } & $A$ & 3.75 & 4.32 & 4.91 & 5.53 & 6.16 & 6.8 & 7.45 \\
\hline & $B$ & 1.5 & 1.86 & 2.26 & 2.71 & 3.21 & 3.75 & 4.33 \\
\hline & $C$ & 0.37 & 0.5 & 0.66 & 0.85 & 1.09 & 1.38 & 1.71 \\
\hline \multirow{3}{*}{ CTO } & $A$ & 92.74 & 93.31 & 93.9 & 94.51 & 95.14 & 95.79 & 96.43 \\
\hline & $B$ & 96.3 & 96.65 & 97.06 & 97.51 & 98.01 & 98.55 & 99.12 \\
\hline & $C$ & 101.5 & 101.63 & 101.79 & 101.98 & 102.23 & 102.51 & 102.85 \\
\hline
\end{tabular}

N.B. The values of the options and of the CTO were obtained assuming a yield curve rising $(A)$, flat $(B)$ or falling $(C)$, for $T=$ 4, $s=8$ and $T n=10.25$..

TABLE 4 Theoretical prices of the CTO as a function of the option maturity

\begin{tabular}{|c|c|c|c|c|c|c|c|c|}
\hline$T$ & & 1 & 2 & 3 & 4 & 5 & 6 & 7 \\
\hline \multirow{3}{*}{ CALL } & $A$ & 0 & 0.02 & 0.04 & 0.06 & 0.08 & 0.08 & 0.06 \\
\hline & $B$ & 0.26 & 0.5 & 0.6 & 0.62 & 0.56 & 0.44 & 0.26 \\
\hline & $C$ & 2.74 & 3.06 & 2.94 & 2.58 & 2.07 & 1.46 & 0.76 \\
\hline \multirow{3}{*}{ PUT } & $A$ & 9.92 & 8.54 & 7.05 & 5.53 & 4.05 & 2.63 & 1.28 \\
\hline & $B$ & 4.6 & 4.03 & 3.38 & 2.71 & 2.05 & 1.38 & 0.7 \\
\hline & $C$ & 0.98 & 1.07 & 0.99 & 0.85 & 0.69 & 0.5 & 0.28 \\
\hline \multirow{3}{*}{ CTO } & $A$ & 98.9 & 97.53 & 96.03 & 94.51 & 93.03 & 91.61 & 90.27 \\
\hline & $B$ & 99.39 & 98.82 & 98.17 & 97.51 & 96.84 & 96.18 & 95.5 \\
\hline & $C$ & 102.11 & 102.2 & 102.12 & 101.98 & 101.82 & 101.64 & 101.41 \\
\hline
\end{tabular}

N.B. The values of the options and of the CTO were obtained assuming a yield curve rising $(A)$, flat $(B)$ or falling $(C)$, for $K=$ $100, s=8$ and $T n=10.25$.

lying security. The second of these effects is due to the relationship between the option exercise date $(T)$ and the maturity of the underlying bond $(s)$. When $s$ is very large compared with $T$, an increase in $T$ increases the dispersion of the bond prices at the option exercise date. Conversely, when $s$ is close to $T$, an increase in $T$ reduces their dispersion. ${ }^{8}$ Since the value of an option increases with the variability of the price of the underlying security, it follows that lengthening the maturity of the option initially increases and subsequently decreases the value of the CTO.

The net result of the two effects just described (the first always negative and the second not always positive) is that the price of the options tends to be a decreasing function of $T$. Accordingly, the longer the maturity of the option, the lower the current value of CTOs (Table 4)

\subsection{Bond maturity}

Lengthening the maturity of the CTOs also produces two effects: on the one hand, it increases the value of the options because it increases the variability of the price of the underlying bond and, on the other, it alters their expected value at the exercise date. With a rising yield curve, the expected price of the underlying bond decreases as the maturity $(s)$ lengthens, with the result that the value of the call option decreases and that of the put option increases, and vice-versa for a falling yield curve.

\footnotetext{
${ }^{8}$ In the limiting case of $T=s$, the price of the underlying bond at the option exercise date is known: $B(T, T, T n)=1$.
} 
TABLE 5 Theoretical prices of the CTO as a function of the bond maturity

\begin{tabular}{rrrrrrrrr}
\hline \multicolumn{1}{c}{$s$} & 5 & 6 & 7 & 8 & 9 & 10 & 11 \\
\hline \multirow{4}{*}{ CALL } & $A$ & 0.09 & 0.11 & 0.09 & 0.06 & 0.04 & 0.02 & 0.01 \\
& $B$ & 0.31 & 0.49 & 0.58 & 0.62 & 0.62 & 0.59 & 0.56 \\
& $C$ & 0.78 & 1.46 & 2.05 & 2.58 & 3.07 & 3.52 & 3.93 \\
\hline \multirow{3}{*}{ PUT } & $A$ & 1.59 & 3.03 & 4.34 & 5.53 & 6.62 & 7.61 & 8.51 \\
& $B$ & 0.92 & 1.65 & 2.24 & 2.71 & 3.11 & 3.45 & 3.74 \\
& $C$ & 0.43 & 0.68 & 0.81 & 0.85 & 0.85 & 0.83 & 0.77 \\
\hline \multirow{2}{*}{ CTO } & $A$ & 94.55 & 94.56 & 94.54 & 94.51 & 94.49 & 94.47 & 94.46 \\
& $B$ & 97.21 & 97.38 & 97.48 & 97.51 & 97.51 & 97.49 & 97.45 \\
& $C$ & 100.19 & 100.86 & 101.45 & 101.98 & 102.47 & 102.93 & 103.34 \\
\hline
\end{tabular}

N.B. The values of the options and of the CTO were obtained assuming a yield curve rising $(A)$, flat $(B)$ or falling $(C)$, for $K=$ $100, T=4$ and $T n=10.25$.

TABLE 6 Theoretical prices of the CTO as a function of the coupon rate

\begin{tabular}{rrrrrrrrr}
\hline \multicolumn{1}{c}{ Tn } & & 8.00 & 8.75 & 9.50 & 10.25 & 11.00 & 11.75 & 12.50 \\
\hline \multirow{4}{*}{ CALL } & $A$ & 0.09 & 0.11 & 0.09 & 0.06 & 0.04 & 0.02 & 0.01 \\
& $B$ & 0.31 & 0.49 & 0.58 & 0.62 & 0.62 & 0.59 & 0.56 \\
& $C$ & 0.78 & 1.46 & 2.05 & 2.58 & 3.07 & 3.52 & 3.93 \\
\hline \multirow{2}{*}{ PUT } & $A$ & 1.59 & 3.03 & 4.34 & 5.53 & 6.62 & 7.61 & 8.51 \\
& $B$ & 0.92 & 1.65 & 2.24 & 2.71 & 3.11 & 3.45 & 3.74 \\
& $C$ & 0.43 & 0.68 & 0.81 & 0.85 & 0.85 & 0.83 & 0.77 \\
\hline \multirow{2}{*}{ CTO } & $A$ & 94.55 & 94.56 & 94.54 & 94.51 & 94.49 & 94.47 & 94.46 \\
& $B$ & 97.21 & 97.38 & 97.48 & 97.51 & 97.51 & 97.49 & 97.45 \\
& $C$ & 100.19 & 100.86 & 101.45 & 101.98 & 102.47 & 102.93 & 103.34 \\
\hline
\end{tabular}

N.B. The values of the options and of the CTO were obtained assuming a yield curve rising $(A)$, flat $(B)$ or falling $(C)$, for $K=$ $100, T=4$ and $s=8$.

The net result of the two effects just described (the first always positive and the second not always negative) is that the price of the options tends to be an increasing function of $s$. Accordingly, the longer the maturity of the CTOs, the higher their current value (Table 5).

\subsection{Coupon rate}

The higher the coupon rate, the greater the probability that CTOs will be held to maturity, with the result that the value of the extension (call) option is higher and that of the early redemption (put) option is lower. Furthermore, since a CTO with a higher coupon rate is obviously more advantageous than an otherwise equal bond, the value of the CTO must be an increasing function of the coupon rate (Table 6).

\section{CONCLUSIONS}

On the assumption that CTOs are issued with the aim of lengthening the average maturity of the public debt, the Treasury should maximize the value of the extension option to increase the probability of holders keeping their securities until maturity.

The foregoing analysis shows that this objective can be achieved by reducing the early redemption price $(K)$ and increasing the coupon rate $(T n)$. The choice of the maturity and of the early redemption date depend instead on the current shape of the yield curve. When this is rising, these factors are relatively unimportant, while when it is falling, it would be to the Treasury's advantage to anticipate the early redemption date $(T)$ and lengthen the maturity $(s)$. 
APPENDIX A

TABLE a1 Theoretical Prices and Net Interest Rates

\begin{tabular}{|c|c|c|c|c|c|}
\hline \multirow{3}{*}{ Maturity } & \multicolumn{4}{|c|}{$\begin{array}{l}\text { Raw data: Treasury bonds } \\
\text { Stock Exchange and Wire Market Prices } \\
\text { (Monday } 28 \text { November 1988) }\end{array}$} & \\
\hline & \multirow{2}{*}{ Theoretical price } & \multirow{2}{*}{ Spot rate } & \multicolumn{3}{|c|}{ Forward rate } \\
\hline & & & 3 months & 6 months & 1 year \\
\hline 3 months & 97.64 & 10.19 & 10.34 & 10.42 & 10.55 \\
\hline 6 months & 95.16 & 10.27 & 10.49 & 10.56 & 10.68 \\
\hline 1 year & 90.57 & 10.41 & 10.75 & 10.81 & 10.91 \\
\hline 2 years & 81.66 & 10.66 & 11.16 & 11.20 & 11.28 \\
\hline 3 years & 73.38 & 10.87 & 11.47 & 11.50 & - \\
\hline
\end{tabular}

TABLE a2 Differentials between Actual and Theoretical Prices

\begin{tabular}{|c|c|c|c|c|c|}
\hline \multirow[b]{2}{*}{ A.B.I. Code } & \multicolumn{3}{|c|}{$\begin{array}{l}\text { Raw data: Treasury bonds } \\
\text { Stock Exchange and Wire Market Prices } \\
\text { (Monday } 28 \text { November 1988) }\end{array}$} & \multirow[b]{2}{*}{ Theoretical Price } & \multirow[b]{2}{*}{ Differentia } \\
\hline & Security & Tax Rate & Actual Price & & \\
\hline 12491 & ВТР $1.1 .8912 .50 \%$ & - & 100.10 & 100.11 & -0.01 \\
\hline 12494 & ВТР $1.2 .8912 .50 \%$ & - & 100.60 & 100.32 & 0.28 \\
\hline 12496 & ВТР $1.3 .8912 .50 \%$ & - & 100.65 & 100.58 & 0.07 \\
\hline 12499 & BTP $1.4 .8912 .00 \%$ & - & 100.60 & 100.55 & 0.05 \\
\hline 12601 & ВТР $1.5 .8910 .50 \%$ & - & 100.30 & 100.16 & 0.14 \\
\hline 12492 & ВТР $1.1 .9012 .50 \%$ & - & 102.30 & 102.23 & 0.07 \\
\hline 12610 & ВТР $1.1 .909 .25 \%$ & 6.25 & 98.56 & 98.34 & 0.21 \\
\hline 12495 & ВТР $1.2 .9012 .50 \%$ & - & 102.40 & 102.38 & 0.02 \\
\hline 12612 & ВТР $1.2 .909 .25 \%$ & 6.25 & 98.15 & 98.22 & -0.07 \\
\hline 12497 & ВТР $1.3 .9012 .50 \%$ & - & 102.75 & 102.58 & 0.17 \\
\hline 12614 & ВТР $1.3 .909 .15 \%$ & 6.25 & 97.95 & 98.04 & -0.09 \\
\hline 12628 & ВТР $1.3 .9010 .50 \%$ & 12.50 & 98.64 & 98.67 & -0.03 \\
\hline 12629 & ВТР $15.3 .9010 .50 \%$ & 12.50 & 98.45 & 98.64 & -0.19 \\
\hline 12600 & ВТР $1.4 .9012 .00 \%$ & - & 102.10 & 102.08 & 0.02 \\
\hline 12616 & BTP $1.4 .909 .15 \%$ & 6.25 & 97.65 & 97.86 & -0.21 \\
\hline 12630 & ВТР $1.4 .9010 .50 \%$ & 12.50 & 98.45 & 98.58 & -0.13 \\
\hline 12632 & ВТР $15.4 .9010 .50 \%$ & 12.50 & 98.50 & 98.48 & 0.02 \\
\hline 12602 & ВТP $1.5 .9010 .50 \%$ I & - & 100.20 & 100.27 & -0.07 \\
\hline 12618 & BTP $1.5 .909 .15 \%$ & 6.25 & 97.80 & 97.74 & 0.06 \\
\hline 12633 & ВТP $1.5 .9010 .50 \%$ II & 12.50 & 98.55 & 98.48 & 0.07 \\
\hline 12635 & ВТР $18.5 .9010 .50 \%$ & 12.50 & 98.50 & 98.46 & 0.04 \\
\hline 12603 & ВТР $1.6 .9010 .00 \%$ & - & 99.65 & 99.62 & 0.03 \\
\hline 12620 & BTP $1.6 .909 .15 \%$ & 6.25 & 97.60 & 97.62 & -0.02 \\
\hline 12604 & ВТР $1.7 .909 .50 \%$ & - & 98.60 & 98.82 & -0.22 \\
\hline 12622 & ВТР $1.7 .9010 .50 \%$ & 6.25 & 99.40 & 99.30 & 0.10 \\
\hline 12605 & ВТР $1.8 .909 .50 \%$ & - & 98.80 & 98.74 & 0.06 \\
\hline 12624 & ВТР $1.8 .9010 .50 \%$ & 6.25 & 99.15 & 99.20 & -0.05 \\
\hline 12606 & BTP $1.9 .909 .25 \%$ & - & 98.15 & 98.21 & -0.06 \\
\hline 12625 & ВТР $1.9 .9011 .25 \%$ & 12.50 & 99.10 & 99.03 & 0.07 \\
\hline 12641 & ВTP $1.9 .9011 .50 \%$ & 12.50 & 99.20 & 99.38 & -0.18 \\
\hline 12607 & ВTP $1.10 .909 .25 \%$ & 6.25 & 96.80 & 97.15 & -0.35 \\
\hline
\end{tabular}


TABLE a2 (cont.) Differentials between Actual and Theoretical Prices

\begin{tabular}{|c|c|c|c|c|c|}
\hline \multicolumn{6}{|c|}{$\begin{array}{l}\text { Raw data: Treasury bonds } \\
\text { Stock Exchange and Wire Market Prices } \\
\text { (Monday } 28 \text { November 1988) }\end{array}$} \\
\hline A.B.I. Code & Security & Tax Rate & Actual Price & Theoretical Price & Differential \\
\hline 12641 & ВТР $1.9 .9011 .50 \%$ & 12.50 & 99.20 & 99.38 & -0.18 \\
\hline 12607 & ВТР $1.10 .909 .25 \%$ & 6.25 & 96.80 & 97.15 & -0.35 \\
\hline 12626 & ВТР $1.10 .9011 .50 \%$ & 12.50 & 99.40 & 99.44 & -0.04 \\
\hline 12608 & ВТР $1.11 .909 .25 \%$ & 6.25 & 96.56 & 96.99 & -0.43 \\
\hline 12609 & ВТР $1.12 .909 .25 \%$ & 6.25 & 97.00 & 96.85 & 0.15 \\
\hline 12498 & ВТР $1.3 .9112 .50 \%$ & - & 103.85 & 104.03 & -0.18 \\
\hline 12611 & ВТР $1.1 .929 .25 \%$ & 6.25 & 94.59 & 94.96 & -0.38 \\
\hline 12613 & ВTP $1.2 .929 .25 \%$ & 6.25 & 94.65 & 94.78 & -0.13 \\
\hline 12627 & ВТР $1.2 .9211 .00 \%$ & 12.50 & 96.95 & 97.25 & -0.30 \\
\hline 12615 & ВТР $1.3 .929 .15 \%$ & 6.25 & 93.75 & 94.43 & -0.68 \\
\hline 12617 & ВТР $1.4 .929 .15 \%$ & 6.25 & 94.55 & 94.29 & 0.26 \\
\hline 12631 & ВТР $1.4 .9211 .00 \%$ & 12.50 & 96.85 & 97.05 & -0.20 \\
\hline 12619 & ВTP $1.5 .929 .15 \%$ & 6.25 & 94.40 & 94.09 & 0.31 \\
\hline 12634 & ВТР $1.5 .9211 .00 \%$ & 12.50 & 97.00 & 96.87 & 0.13 \\
\hline 12621 & ВTP $1.6 .929 .15 \%$ & 6.25 & 96.75 & 94.01 & 2.74 \\
\hline 12623 & ВТР $1.7 .9210 .50 \%$ & 6.25 & 98.95 & 97.59 & 1.36 \\
\hline 12642 & ВТР $1.9 .9212 .50 \%$ & 12.50 & 99.50 & 100.62 & -1.12 \\
\hline 12644 & ВТР $1.10 .9212 .50 \%$ & 12.50 & 99.52 & 100.61 & -1.09 \\
\hline
\end{tabular}

N.B. The theoretical prices were calculated on the basis of the net yield curve obtained by estimating the Cox, Ingersoll and Ross model. 


\section{REFERENCES}

ANANTHANARAYANAN, A. - SCHWARTZ, E. (1980), "Retractable and Extendible Bonds: The Canadian Experience", Journal of Finance, n. 1, pp. 31-47.

BARONE, E. - CESARI, R. (1986), "Rischio e rendimento dei titoli a tasso fisso e a tasso variabile in un modello stocastico univariato", Banca d'Italia, Temi di discussione, n. 73.

BRENNAN, M. - SCHWARTZ, E. (1977), "Savings Bonds, Retractable Bonds and Callable Bonds", Journal of Financial Economics, n. 5, pp. 67-88.

BRENNAN, M. - SCHWARTZ, E. (1978), "Finite Difference Methods and Jump Processes Arising in the Pricing of Contingent Claims: A Synthesis", Journal of Financial and Quantitative Analysis, n. 3, pp. 461-474.

BROWN, R. - SCHAEFER, S. (1988), "Testing the Cox, Ingersoll \& Ross Model on British Government Index-Linked Securities", London Business School, (IFA-109-88).

BROWN, S. - DYBVIG, P (1986), "The Empirical Implications of the Cox, Ingersoll, Ross Theory of the Term Structure of Interest Rates", Journal of Finance, n. 3, pp. 617-632.

COX, J. - INGERSOLL, J. - ROSS, S. (1985), "A Theory of the Term Structure of Interest Rates", Econometrica, n. 2, pp. 385-407.

GESKE, R. - SHASTRI, K. (1985), "Valuation by Approximation: Alternative Option Valuation Techniques", Journal of Financial and Quantitative Analysis, n. 1, pp. 45-71.

GIBBONS, M. - RAMASWAMY, K. (1986), “The Term Structure of Interest Rates: Empirical Evidence", Unpublished Working Paper.

JAMSHIDIAN, F. (1989), “An Exact Bond Option Formula”, Journal of Finance, no. 1, pp. 205-209. 